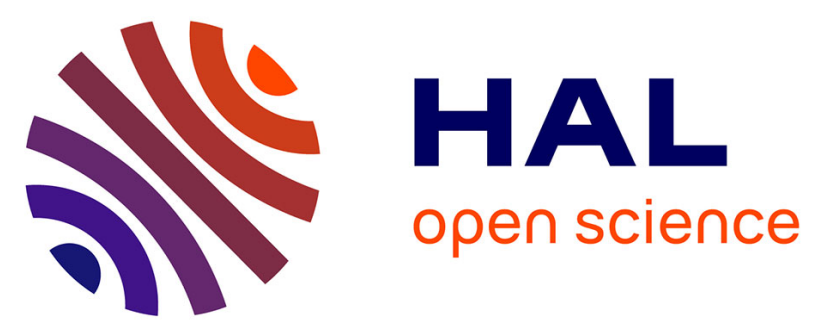

\title{
Thermal interaction of middle and upper crust during gneiss dome formation: Example from the Montagne Noire (French Massif Central)
}

Kévin Fréville, Bénédicte Cenki-Tok, Pierre Trap, M. Rabin, A. Leyreloup, J.-L. Régnier, D.L. Whitney

\section{To cite this version:}

Kévin Fréville, Bénédicte Cenki-Tok, Pierre Trap, M. Rabin, A. Leyreloup, et al.. Thermal interaction of middle and upper crust during gneiss dome formation: Example from the Montagne Noire (French Massif Central). Journal of Metamorphic Geology, 2016, 34, pp.447-462. 10.1111/jmg.12188 . insu01290388

\section{HAL Id: insu-01290388 \\ https://hal-insu.archives-ouvertes.fr/insu-01290388}

Submitted on 17 May 2016

HAL is a multi-disciplinary open access archive for the deposit and dissemination of scientific research documents, whether they are published or not. The documents may come from teaching and research institutions in France or abroad, or from public or private research centers.
L'archive ouverte pluridisciplinaire HAL, est destinée au dépôt et à la diffusion de documents scientifiques de niveau recherche, publiés ou non, émanant des établissements d'enseignement et de recherche français ou étrangers, des laboratoires publics ou privés.

\section{(이)(\$)}

Distributed under a Creative Commons Attribution - NonCommercial - NoDerivatives $\mid 4.0$ 
Received Date : 02-Apr-2015

Revised Date : 02-Mar-2016

Accepted Date : 03-Mar-2016

Article type : Original Article

\title{
Thermal interaction of middle and upper crust during gneiss dome formation: Example from the Montagne Noire (French Massif Central)
}

\author{
K. FRÉVILLE ${ }^{1,5}$, B. CENKI-TOK ${ }^{1}$, P. TRAP ${ }^{2}$, M. RABIN², A. LEYRELOUP ${ }^{1}$, J.-L. \\ RÉGNIER ${ }^{3}$ AND D.L. WHITNEY ${ }^{4}$
}

1 UMR-CNRS 5243 Géosciences Montpellier, Université de Montpellier, place E. Bataillon, 34090 Montpellier, France.

${ }^{2}$ UMR-CNRS 6249 Chrono environnement, Université Franche-Comté, UFR Sciences et Techniques, 16 route de Gray, 25030 Besançon Cedex, France.

${ }^{3}$ Department of Geological Engineering, Faculty of Engineering, Muğla University, TR48000 Muğla, Turkey

${ }^{4}$ Department of Earth Sciences, University of Minnesota, Minneapolis, Minnesota 55455, USA

${ }^{5}$ Institut des Sciences de la Terre d'Orléans (ISTO), Université d'Orléans-CNRS/ INSUBRGM 7327, Campus Géosciences, 1 A Rue de la Férollerie 45071 Orléans Cedex 2,

France

This article has been accepted for publication and undergone full peer review but has not been through the copyediting, typesetting, pagination and proofreading process, which may lead to differences between this version and the Version of Record. Please cite this article as doi:

10.1111/jmg. 12188

This article is protected by copyright. All rights reserved. 
Corresponding Author mail id : Benedicte.Cenki-Tok@gm.univ-montp2.fr

\section{ABSTRACT}

This paper aims to decipher the thermal evolution of the Montagne Noire Axial Zone (southern French Massif Central) gneiss core and its metasedimentary cover through determination of $P-T$ paths and temperature gradients. Migmatitic gneiss from the core of the dome record a clockwise evolution culminating at $725 \pm 25^{\circ} \mathrm{C}$ and $0.8 \pm 0.1 \mathrm{GPa}$ with partial melting, followed by a decompression path with only minor cooling to $690 \pm$ $25^{\circ} \mathrm{C}$ and $0.4 \pm 0.1 \mathrm{GPa}$. Field structural analyses as well as detailed petrological observations interpreted in a petrogenetic grid indicate that the cover sequence experienced LP-HT metamorphism at $<0.4 \mathrm{GPa}$. Apparent thermal gradients within the cover were determined with garnet-biotite thermometry and Raman Spectroscopy on Carbonaceous Matter (RSCM). High temperature apparent gradients (e.g. $\sim 530^{\circ} \mathrm{C} . \mathrm{km}^{-1}$ along one transect) are explained by late brittle-ductile extensional shearing evidenced by phyllonites that post-date peak metamorphism. In areas where normal faults are less abundant and closely spaced, gradients of $\sim 20^{\circ}$ to $50^{\circ} \mathrm{C} \cdot \mathrm{km}^{-1}$ are calculated. These gradients can be accounted for by a combination of dome emplacement and ductile shearing (collapse of isotherms), without additional heat input. Finally, the thermal evolution of the Montagne Noire Axial Zone is typical for many gneiss domes worldwide as well as with other LP-HT terranes in the Variscides.

KEYWORDS: Montagne Noire, gneiss dome, thermal gradients, $P$ - $T$ evolution 


\section{INTRODUCTION}

Many metamorphic domes are described around the world (Teyssier \& Whitney, 2002; Whitney et al., 2004, 2013) in both ancient and modern orogens. These offer the opportunity to view the upper and middle/lower crust along continuous cross-sections from the shallow to deeper crust and are therefore excellent targets for the study of thermal gradients that are obliquely exposed, from low-grade to high-grade metamorphic rocks, including to the zone of crustal melting. Generally, the variation of thermal regimes in large-scale terranes reflects changes in orogenic processes through geologic times (Brown, 2007, 2014). However, at regional scale, high apparent geothermal gradients that may exceed $60^{\circ} \mathrm{C} . \mathrm{km}^{-1}$ within the upper crust (e.g., Mezger, 2005; Laumonier et al., 2010) have been described for many gneiss domes. Such high thermal gradients producing low-pressure - high-temperature (LP-HT) metamorphic sequences have been interpreted to result from crustal thinning in a post-collisional context with mantle uplift and underplating of hot mafic magma (Thompson \& England, 1984; Althoff et al., 1994). This is particularly the case for LP-HT gneiss domes that are widespread in the Variscides (Lardeaux, 2014).

Defining thermal gradients is a challenging task because the proximal metasedimentary envelope that typically mantles gneiss dome cores is a preferential site for strain localization, with the common development of normal brittle-ductile shearing and the emplacement of migmatitic/granitic bodies. In this context, it is difficult to distinguish between real and apparent, regional and local gradients without accurate knowledge of $P-T$ conditions. Some studies have proposed temperature and geothermal 
gradients based on petrogenetic grid analyses (Thompson \& Bard, 1982; Vielzeuf, 1996). However, the $P-T$ conditions obtained with this approach are only qualitative, and the slope of the gradient has no quantitative significance (Vielzeuf, 1996). The eastern part of the Montagne Noire gneiss dome (southern French Massif Central; Fig. 1a) shows nearly continuous exposures from the very low-grade upper crust to the migmatitic middle crust. It is therefore an excellent site for quantifying thermal gradients around and within domes with respect to deformation and thermal conduction during dome emplacement, and thereby understanding the development of this common type of LP-HT terrane.

The aim of this study is to decipher the thermal evolution of the Montagne Noire Axial Zone (MNAZ) gneiss core and its metasedimentary cover through determination of $P-T$ paths and temperature gradients. We use an integrated approach combining field structural analyses, classical petrology, garnet-biotite thermometry, Raman Spectroscopy on Carbonaceous Matter (RSCM) and equilibrium assemblage diagram calculation through thermodynamic forward modelling (Theriak-Domino). The correlation between the documented $P-T$ path and temperature gradients reveals that the thermal state of the middle and upper crust during dome formation is nearly consistent with a single melt-enhanced geotherm.

This article is protected by copyright. All rights reserved. 


\section{GEOLOGICAL SETTING}

\section{Structure and evolution}

In the French Variscan belt, metamorphic domes are described in the Pyrenees (e.g., Aston-Hospitalet; Mezger, 2005; Denèle et al., 2007, 2009; Mezger, 2009) and the French Massif Central (e.g., Velay: Ledru et al., 2001; Levezou: Nicollet, 1978; Montagne Noire: Echtler \& Malavieille, 1990; Van den Driessche \& Brun, 1992; Faure, 1995; Demange, 1999; Aerden \& Malavieille, 1999). The French Massif Central is described as a nappe pile (see for example reviews in Lardeaux, 2014) composed of six units namely, from south to north: i) a foreland basin mostly composed of Visean turbidites; ii) the Montagne Noire gneiss dome; iii) a metasedimentary sequence Palaeozoic in age (the para-autochtonous domain); iv) the Lower Gneiss unit (LGU) composed of amphibolite-facies metasedimentary rocks; v) the Upper Gneiss unit (UGU) composed of mafic as well as felsic rocks and vi) the uppermost Brévenne and Morvan units mostly of oceanic affinity).

The Montagne Noire dome is located at the southwestern tip of the Massif Central (Fig. 1a). This $20 \mathrm{~km}$ wide and $80 \mathrm{~km}$ long dome consists of three ENE-WSW elongated domains (Fig. 1b): i) the northern flank is composed of isoclinal folds and Palaeozoic tectonic units composed of low-grade metasedimentary rocks; ii) the southern flank is composed of a km-scale inverted fold and nappe system involving Palaeozoic rocks (Cambrian to Visean formations) that have been slightly metamorphosed; and iii) the Montagne Noire Axial Zone (MNAZ) is composed of a migmatite dome associated with anatectic granites (Gèze, 1949; Schuilling, 1960) surrounded by metasedimentary 
envelope made of "Schistes X", probably Cambrian in protolith age (Bodganoff et al., 1984).

The MNAZ dome (Fig. 1b) is one of the best-studied metamorphic domes in the world. It has been the subject of constant work since the pioneering study of Gèze (1949). Indeed, great exposure from the very low-grade upper crust toward the migmatitic deeper crust makes the MNAZ a great site for studying deformation and metamorphism at different levels within the orogenic crust. However, the origin of the dome is still debated. Several authors propose very different tectonic models (Echtler \& Malavieille, 1990; Van den Driessche \& Brun, 1992; Faure, 1995; Matte et al., 1998; Demange, 1999; Aerden \& Malavieille, 1999; Franke et al., 2011). A first-order disagreement is exemplified in recent studies proposing that the flow of crust and building of the axial zone formed either in (i) an extensional setting with upper crustal stretching and upward flow of partially molten crust (Van den Driessche \& Brun, 1992; Rey et al., 2011) or (ii) in a compressional setting (Demange, 1999; Charles et al., 2009; Malavieille, 2010; Franke et al., 2011; Rabin et al., 2015).

Recently, the MNAZ gneiss dome has been described as a double-dome consisting of two sub-domes, the Laouzas-Espinouse (north) and the Somail-Caroux or Nore (south) (Fig. 1c; Rey et al., 2011; Withney et al., 2015). Such an architecture consisting of two domes separated by a steeply dipping high-strain zone (Bouchardon et al., 1979) could be common to many metamorphic domes (Rey et al., 2011). The double-dome structure is predicted by 2D numerical simulations (Tirel et al., 2004; Rey et al., 2011). 
However, this double-dome structure is still highly controversial (e.g., Van Den Driessche \& Pitra, 2012 versus Rey et al., 2012). According to Van Den Driessche \& Pitra (2012), the double-dome model does not apply to the MNAZ. In particular, they stated that the deformation gradient across the steep high-strain zone in the eastern part of the dome (where the double-dome structure is well developed) could be related to an extensional shearing and develops upward (Van Den Driessche \& Pitra, 2012), and not subsequently in a horizontal direction as described in Rey et al. $(2011,2012)$.

Recently, Rabin et al. (2015) performed a detailed structural analysis and proposed that the finite strain pattern of the MNAZ is made of superimposition of three deformation events, named D1, D2 and D3. Figure $1 \mathrm{~b}$ shows the S1, S2 and S3 foliation trajectories that make the MNAZ architecture. S1 is an early flat-lying foliation, folded in upright ENE-WSW D2 folds. Within the migmatitic dome core, D2 localizes along an E-W trending high-strain corridors (D2; Fig. 1b), where S1 is transposed by a subvertical S2 foliation. The D2 high-strain corridors (HSC) prolongates eastward in the Rosis synform (Fig. 1b,c). In the upper crust, and along the core/envelope boundary, S1 and S2 are transposed into a subhorizontal foliation S3 that forms a transition zone (Rabin et al., 2015). The D3 transition zone accommodated vertical shortening during coaxial thinning and NE-SW to E-W directed stretching (Rabin et al., 2015). This transition zone separates two domains of distinct metamorphic grade. Below the S3 transition zone, rocks are partially molten with metapelitic garnet-cordierite-bearing metatexite and migmatitic orthogneiss. Above the $\mathrm{S} 3$ transition zone, rocks do not show any evidence of partial melting (Rabin et al., 2015). 
In the eastern part of the MNAZ, Rey et al. (2011) interpreted the S3 transition zone as a detachment that accommodated eastward escape of the middle crust. Many studies show an eastward flow of the upper crust in the eastern termination of the dome, parallel to the axial plane of the major axis of the dome core (e.g., van den Driessche \& Brun, 1992). More recently, Rabin et al. (2015) proposed a similar process in the western part of the MNAZ. At the centre of the dome, partial melting is considered to have been synchronous with the main deformation event (Brunel \& Lansigu, 1997; Rabin et al., 2015).

The northern boundary of the MNAZ is marked by a ductile fault (Mont de Lacaune Fault; Fig. 1) whose last increment, at least, was normal (Echtler \& Malavieille, 1990; Pitra et al., 2012). The southern boundary of the MNAZ is marked by the Mons fault bundle, which is sub-vertical in the eastern part and moderately south dipping in its western prolongation. The metapelitic cover ("Schistes X") was affected by normal ductile shear zones in the eastern part of the Espinouse sub-dome (van den Driessche \& Brun, 1989; Brunel \& Lansigu, 1997; Fig. 1c).

\section{Overview of Montagne Noire metamorphism}

Early workers defined the MNAZ as a migmatitic dome formed from Precambrian and Cambrian sedimentary protoliths during Caledonian orogenesis (Roques, 1941; Schuilling, 1960). The first petrological work within the Montagne Noire dates back to the late 70's and early 80's (e.g., Bard \& Ramboloson, 1973; Bouchardon et al., 1979; Thompson \& Bard, 1982). From the study of metamorphic rocks, two generations of 
minerals have been observed, corresponding with two metamorphic phases. First, rare evidence of kyanite is considered a fingerprint of an earlier medium pressure - medium temperature event (MP-MT; Demange, 1985; Soula et al., 2001; Alabouvette et al., 2003; Faure et al., 2014). Peak metamorphic conditions for omphacite-garnet-quartzrutile eclogite bodies within the migmatitic core of the dome were estimated at $0.9 \pm 0.2$ GPa and $750^{\circ} \mathrm{C}$ by Demange (1985). Recent reevaluation of these conditions by Franke et al., (2011) using the petrological data of Demange (1985) yielded higher pressures at $0.14 \mathrm{GPa}$ for a minimum peak temperature of $650^{\circ} \mathrm{C}$. If this metamorphism was related to the Variscan evolution of the dome rocks, these petrological data along with the peak metamorphic conditions recorded by the gneiss/migmatite indicate an overall clockwise $P-T$ path, such as outlined by Soula et al. (2001) for an early MP-MT metamorphism (M1) followed by an LP-HT (M2) metamorphism.

The low pressure - high temperature (LP-HT, 0.35-0.5 GPa, 500-700 ${ }^{\circ} \mathrm{C}$ ) metamorphic imprint is well observed and marked by isograds wrapping around the gneissic core, especially in the eastern termination of the dome (Bogdanoff et al., 1967; Bogdanoff, 1969; Rambeloson, 1972; Bard \& Rambeloson, 1973; Demange \& Gattonni, 1978; Thompson \& Bard, 1982; Ourzik et al., 1991; Demange, 1999; Soula et al., 2001; Alabouvette et al., 2003) (Fig. 1c). In the eastern part of the Montagne Noire, the estimated temperatures of peak metamorphism recorded by the metapelitic "Schistes X" increase towards the anatectic MNAZ (Thompson \& Bard, 1982). Index minerals characterize a succession of five metamorphic zones; from east to west, these are: the chlorite zone (Zchl), the biotite-cordierite zone (Zbi-cd), the staurolite-cordierite zone 
(Zst-cd), the andalusite-biotite zone (Zand-bi), and the sillimanite zone (Zsill). The sillimanite-K-feldspar zone (Zsill-kfs) is only visible in paragneisses of the axial zone (Fig. 1c). All index minerals used to identify these zones are syn-tectonic in relation to development of the main foliation (Rambeloson, 1972; Bouchardon et al., 1979; Beaud, 1985; Van Den Driessche \& Brun, 1992; Brun \& Van Den Driessche, 1994; Soula et al., 2001)

\section{ANALYTICAL METHODS}

Mineral compositions were determined with a Cameca SX100 electron microprobe at the University of Montpellier 2, operating at $20 \mathrm{kV}$ accelerating voltage and $15 \mathrm{nA}$ beam current. Representative mineral compositions are presented in Table 1. Thermodynamic calculations were made in the simplified model system $\mathrm{Na}_{2} \mathrm{O}-\mathrm{CaO}-\mathrm{K}_{2} \mathrm{O}-\mathrm{FeO}-\mathrm{MgO}-$ $\mathrm{Al}_{2} \mathrm{O}_{3}-\mathrm{SiO}_{2}-\mathrm{H}_{2} \mathrm{O}$, and the amount of water used in the $P-T$ pseudosection calculations was estimated from a $\mathrm{T}-\mathrm{M}\left(\mathrm{H}_{2} \mathrm{O}\right)$ pseudosection so that the assemblage is just watersaturated below the solidus at mid-crustal pressure and that free water disappears within $10-20{ }^{\circ} \mathrm{C}$ once the solidus is reached (White et al. 2002). The database of Holland \& Powell (1998; thermodynamic database of THERMOCALC, version 3.21) was used, including recent updates (Holland \& Powell, 1998; Baldwin et al., 2005; Kelsey et al., 2005; White et al., 2007). Rock-specific equilibrium assemblage diagrams were calculated with the free energy minimization programs THERIAK and DOMINO (de Capitani \& Petrakakis, 2010). Solution models used for computation are indicated in Table 2. Bulk rock compositions were obtained by ICP-AES on rock powders at the University of Clermont-Ferrand (Table 3). Mineral abbreviations are from Whitney \& Evans (2010).

This article is protected by copyright. All rights reserved. 
Raman Spectroscopy on Carbonaceous Matter (RSCM) was used following the method proposed by Beyssac et al. (2002), which uses inelastic light diffusion in organic matter. This method consists of studying Raman spectra to determine the degree of polymerization (graphitisation) of carbonaceous matter (Williams, 1995). The carbonaceous matter is polymerized when temperature increases and the Raman spectra are accordingly modified. Beyssac et al. (2002) presented an empirical formulation between the shape of Raman spectra and temperature. Temperatures were obtained on a Raman RENISHAW micro-spectrometer at the Université Pierre et Marie Curie (UMPMC). All data assume $\pm 40^{\circ} \mathrm{C}$ of measurement uncertainty. The carbonaceous matter analysed is located within the main planar fabric and may be considered as synchronous with deformation and metamorphism. With the exception of one sample profile (the Northern Espinouse Profile, NEP), which does not contain garnet, garnet-biotite thermometry was also used to determine temperatures for metasedimentary rocks.

\section{RESULTS}

In its eastern termination, the MNAZ is characterized by three domains composed mostly of gneiss and anatectic granite: the Espinouse sub-dome in the northern part, the HSC formed by paragneiss and micaschists in the Rosis synform area and the Caroux sub-dome (Rabin et al., 2015; Fig. 1b). The eastern termination of the MNAZ is overlain by a metapelitic sequence. In the following sections we describe the key petrological features of the gneissic domain and cover sequences and provide thermobarometric data for each.

This article is protected by copyright. All rights reserved. 


\section{Metamorphic evolution of the gneissic core}

Petrographic description and mineralogy

In order to estimate $P-T$ conditions that prevailed in the deepest exposed parts of the MNAZ during dome formation, three migmatitic gneiss samples were collected: two in the Espinouse subdome (MNC04, MNC17) and one in the Caroux (MN11-47) (Fig. 1C). Espinouse sample MNC04 is a migmatitic gneiss composed of biotite, sillimanite, cordierite, quartz, plagioclase, K-feldspar and rare muscovite. Biotite grains form the main foliation and are considered to belong to the peak equilibrium assemblage. Biotite Mg\# is $0.44-0.46$. Muscovite shows a Si (pfu) between 3.01 and 3.05 (Table 1). Locally, millimetric nodules of sillimanite are rimmed by cordierite (Fig. 2a). Espinouse sample MNC17 is a migmatitic gneiss that consists of garnet, biotite, sillimanite, cordierite, quartz, K-feldspar, plagioclase and rare muscovite. Garnet appears as centimetre-sized poikilitic porphyroblasts disseminated within a weakly oriented matrix underlined by biotite (Fig. 2b). Most of the garnet crystals are highly corroded. Garnet composition (Table 1 ) is homogeneous and dominated by the almandine end-member (74- $75 \%)$. Other components are spessartine (16-19 \%), pyrope (5-7\%) and grossular (1-2 \%). Biotite $\mathrm{Mg} \#$ is $~ 0.31$.

Caroux sample MN11-47 is a migmatitic gneiss that consists of garnet, biotite, sillimanite, quartz, K-feldspar, plagioclase and rare muscovite. The main planar fabric is marked by elongated biotite crystals. Millimetre-size poikiloblastic garnet porphyroblasts ( $1 \mathrm{~mm}$ in diameter) are scattered within the matrix. Garnet composition is homogeneous and dominated by the almandine end-member (65 - 66\%). Other 
components are $\sim 3 \%$ of grossular, $\sim 12 \%$ of pyrope and $\sim 20 \%$ of spessartine. Biotite $\mathrm{Mg \#}$ is in the range $0.47-0.51$ whereas muscovite's $\mathrm{Si}(\mathrm{pfu})$ is between 3.01 and 3.03 (Table 1).

\section{Thermodynamic modelling}

An equilibrium assemblage diagram for Espinouse sample MNC04 (Fig. 3a) shows a stability field for the observed mineral assemblage of PI-Kfs-Crd-Sil-Bt-Qz-Liq located at $705 \pm 45^{\circ} \mathrm{C}$ and $0.43 \pm 0.1 \mathrm{GPa}$. Mineral textures within Espinouse sample MNC17 (Fig. 3b) may be interpreted in terms of peak (Grt-PI-Kfs-Bt-Ms-Qz-Liq) and retrograde assemblages (PI-Kfs-Sil-Crd-Bt-Qz-Liq), with the appearance of sillimanite and cordierite replacing garnet (pseudomorphs). Using garnet composition ispoleths, the equilibrium assemblage indicates a decompressional path from peak conditions $(723 \pm$ $5{ }^{\circ} \mathrm{C}$ and $\left.0.78 \pm 0.1 \mathrm{GPa}\right)$ to retrograde conditions $\left(695 \pm 33^{\circ} \mathrm{C}\right.$ and $\left.0.33 \pm 0.07 \mathrm{GPa}\right)$. Caroux sample MN11-47 (Fig. 3c) presents an assemblage containing PI-Kfs-Grt-Bt-Sil$\mathrm{Qz}$ and melt that corresponds to metamorphic conditions of $738 \pm 12{ }^{\circ} \mathrm{C}$ and $0.8 \pm 0.07$ GPa according to the equilibrium diagram and grossular isopleths.

To sum up, the thermal evolution of the gneissic core as recorded by the three gneiss samples is characterized by peak conditions culminating at $\sim 725^{\circ} \mathrm{C}$ and $0.8 \mathrm{GPa}$ followed by near isothermal decompression to $~ 0.3 \mathrm{GPa}$.

This article is protected by copyright. All rights reserved. 


\section{Metamorphic evolution of the metasedimentary cover}

Petro-structural map and corresponding petrogenetic semi-quantitative P-T path

The dome cover is characterized by a metapelitic sequence (Fig. 1c). In the eastern termination of the dome, this sequence records a LP-HT metamorphism that was described in detail along one cross-section by Thompson \& Bard (1982) and on the 1/50.000 scale geological map of Bédarieux (Bogdanoff et al., 1984). In this study, we have mapped the entire eastern metapelitic envelope of the dome (Fig. 1c). This work is based on petrographic observations made on 260 thin sections. The petro-structural study of this area allows the definition of six metamorphic zones showing a LP-HT sequence from the chlorite zone to sillimanite zone from $E$ to $W$ (Fig. 1c). Based on this new metamorphic map we define three profiles for quantitative thermal gradients calculation (see below).

In the northeastern part of the Rosis synform and near the Mons fault (Fig. 1c), primary chlorite crystallized at low grade (Zchl), forming small stacks of porphyroblasts in microlithons bounded by oxide-rich cleavage domains (sample bi5; Fig. 4a). Small primary acicular chlorite also occurs in the biotite-cordierite zone. At higher grade, biotite is in textural equilibrium with cordierite (sample Bi1; Fig. 4b), emphasizing a notable jump of temperature relative to nearby phyllonites (Thompson \& Bard, 1982; Van Den Driessche \& Brun, 1992) (Fig. 1c). Primary chlorite and biotite are also present as inclusions in garnet, and texturally late chlorite is common in the matrix.

This article is protected by copyright. All rights reserved. 
In the biotite-cordierite zone, syntectonic cordierite porphyroblasts have curved inclusion trails that indicate top to-the-NE sense of shear (sample bi1; Fig. 4b). The cordierite is, however, commonly pinitized, especially in the staurolite-cordierite zone (Zst-crd), preventing determination of its composition. In some places, cordierite wraps xenoblastic staurolite (samples F1 and PP1; Fig. 4c,d). Cordierite persists into the sillimanite zone.

Staurolite first crystallized in the staurolite-cordierite zone but is also present in the andalusite-biotite and sillimanite zones. Subhedral rotated staurolite is locally present in the andalusite-biotite zone (Fig. 4c).

Euhedral prismatic andalusite in textural equilibrium with biotite occurs up-grade of the staurolite-cordierite zone (Zand-bi; samples bi2 \& bi5; Fig. 4e,f). In addition, andalusite-biotite-staurolite and andalusite-biotite-cordierite have been observed in the andalusite-biotite zone (Fig. 4e,f). Andalusite persists into the sillimanite zone.

Fibrolitic sillimanite occurs as epitaxial inclusions in biotite, as rims around garnet (sample CMS3; Fig. 4g) and as lensoid aggregates within the matrix near the margin with the Axial Zone gneiss.

Rare relict kyanite occurs in staurolite-biotite schist (Fig. 4h) near the eastern termination of the Caroux subdome (Fig. 1c). In this schist, kyanite and staurolite are both corroded, and rutile occurs as an accessory phase.

\section{Garnet-biotite and RSCM thermometry}

In order to get a quantitative estimation of thermal gradients in the metapelitic envelope around the gneissic core, we have studied three cross-sections located in the eastern 
part of the axial zone and orthogonal to the main structures (Fig. 1c). Classical thermometry based on Fe-Mg exchange between garnet and biotite (Fig. 4i, Table 4; Ferry \& Spear, 1978 using the dataset from Holland \& Powell 1998) has been combined with Raman thermometry on organic matter (Fig. 4j; RSCM; Beyssac et al., 2002). Thermal gradients along the three cross-sections (Fig. 5) were calculated using orthogonal projections of the sample location onto the profile and parallel to the main structures (Fig. 6).

Cross section 1 is located near Castanet le Haut and is defined as the Northern Espinouse Profile (NEP; Fig. 5a). It is a $2 \mathrm{~km}$-long N-S cross section that cuts across the pinched metapelitic unit from the Espinouse sub-dome toward the Graissessac basin. In this area the metapelitic unit is affected by the Mont de Lacaune fault (MLF), which corresponds to a series of low angle normal faults (Rabin et al., 2015; Roger et al., 2015). This section crosses two metamorphic zones: the chlorite and sillimanite zones (Fig. 1c). The NEP profile (Fig. 5a) is composed of six samples (distributed over a short distance of $250 \mathrm{~m}$ ) studied with RSCM. It is bounded by samples STGR25 (449 $\left.\pm 35^{\circ} \mathrm{C}\right)$ and STGR16 $\left(566 \pm 38^{\circ} \mathrm{C}\right)$. These data yield an apparent thermal gradient of $537^{\circ} \mathrm{C}^{\mathrm{km}}{ }^{-1}\left(\sim 1790^{\circ} \mathrm{C} . \mathrm{GPa}^{-1}\right.$; (Fig. 6a).

Cross section 2 is a W-E trending, 4 km-long profile located near Rosis (RP; Fig. 5b). This profile is characterized by a late low angle normal fault that divides the andalusite-biotite metamorphic zone and juxtaposed high-grade metamorphic rocks under lower grade metamorphic rocks. Due to the structural position of the samples $\left(\mathrm{S}_{1^{-}}\right.$ $\mathrm{S}_{3}$ ), the RP (Fig. 5b) cannot be interpreted as a single gradient but yields two distinct thermal gradients (Fig. 6b). The RSCM profile is composed of four samples bounded by 
SPP4A $\left(575 \pm 25^{\circ} \mathrm{C}\right)$ and P5 $\left(593 \pm 20^{\circ} \mathrm{C}\right)$. It corresponds to an apparent thermal gradient of $52^{\circ} \mathrm{C} . \mathrm{km}^{-1}$. This gradient can be related to the garnet-biotite gradient calculated from four samples (from PP1C; $522 \pm 26^{\circ} \mathrm{C}$ to $\mathrm{CMS} 1 ; 555 \pm 27^{\circ} \mathrm{C}$ ) yielding $57^{\circ} \mathrm{C} \cdot \mathrm{km}^{-1}$. Another garnet-biotite gradient may be calculated from two samples located in the NW-SE part of the RP (from D5; $613 \pm 32^{\circ} \mathrm{C}$ D8; $644 \pm 35^{\circ} \mathrm{C}$ ), yielding an apparent gradient of $277^{\circ} \mathrm{C} \cdot \mathrm{km}^{-1}\left(\sim 923^{\circ} \mathrm{C} . \mathrm{GPa}^{-1}\right)$.

Cross section 3 is a $2-\mathrm{km}$ long profile oriented SW-NE between Combe and the late eastern normal fault, north of Lamalou les Bains (Fig. 1c). This Eastern Caroux Profile (ECP; Fig. 5c) crosses all six metamorphic zones from the sillimanite zone in Combe to the chlorite zone, north of Lamalou-les-Bains. Unlike the other cross sections, the extent of each metamorphic zone in this profile was not reworked by late low angle normal faults (Fig. 1c). In the ECP (Fig. 5c), garnet-biotite thermometry yields a gradient of $47^{\circ} \mathrm{C} \cdot \mathrm{km}^{-1}$ (from MN49; $522 \pm 26^{\circ} \mathrm{C}$ to MN19; $543 \pm 27^{\circ} \mathrm{C}$; Fig. 7C), in accordance with the gradient based on RSCM $\left(28^{\circ} \mathrm{C} . \mathrm{km}^{-1}\right.$; from SR12; $522 \pm 26^{\circ} \mathrm{C}$ to MN19; $586 \pm$ $\left.31^{\circ} \mathrm{C}\right)$. Owing to the abnormally low value, probably due to this structural position $\left(D_{3}\right.$ phylonite), sample MN13 is excluded from the garnet- biotite calculation.

\section{DISCUSSION}

\section{$P-T$ path of the migmatitic core}

The tectono-thermal evolution of the MNAZ core is recorded by the three samples from the Espinouse and Caroux sub-domes.

The Espinouse sample MNC17 recorded a portion of a clockwise $P-T$ path with high pressure conditions at $\sim 0.8 \pm 0.15 \mathrm{GPa}$ and $725 \pm 25{ }^{\circ} \mathrm{C}$ followed by low pressure 
conditions at $0.35 \pm 0.1 \mathrm{GPa}$ and $690 \pm 25^{\circ} \mathrm{C}$ (Fig. 7). Caroux sample MN11-47 records $P-T$ conditions of $0.8 \pm 0.1 \mathrm{GPa}$ and $730^{\circ} \mathrm{C}$ with no evidence for re-equilibration at lower pressure. On the contrary, the Espinouse sample MNC04 records peak temperature conditions of $700 \pm 50{ }^{\circ} \mathrm{C}$ for low pressure condition of $\sim 0.4 \mathrm{GPa}$. This sample is located along the D3 transition zone, where the reworking of S1 into S3 was strong (Rabin et al., 2015). A similar clockwise metamorphic evolution followed by the migmatitic rocks from the MNAZ core was qualitatively documented by Demange (1985) and Soula et al. (2001) and quantitatively by Rabin et al. (2015) (Fig. 7).

\section{High-temperature gradients within the metasedimentary envelope}

The cover of the MNAZ is a metapelitic sequence with mineral assemblages defining a LP-HT metamorphic gradient. The geometry of metamorphic isograds varies from south to north and is gently pinched near the Rosis synform in response to late contractional deformation (Rabin et al., 2015, Roger et al., 2015). In the eastern prolongation of the Caroux sub-dome, metamorphic zones are wide $(\sim 5-6 \mathrm{~km})$, whereas they tighten in the northeast prolongation of the Espinouse sub-dome. According to Thompson \& Bard (1982), the tightening observed from south to north may be linked to late brittle-ductile top to the east extensional shearing evidenced by phyllonites that post-date peak metamorphism (e.g. in the NEP and RP profiles). In these areas, where normal faults exemplified by phylonites are numerous and tighten, an apparent high temperature gradient of $\sim 530^{\circ} \mathrm{C} . \mathrm{km}^{-1}$ has been calculated (NEP profile).

This article is protected by copyright. All rights reserved. 
In areas where normal faults are less abundant (Rosis profile), gradients of $52^{\circ} \mathrm{C} . \mathrm{km}^{-1}\left(\sim 173^{\circ} \mathrm{C} . \mathrm{GPa}^{-1}\right)$ and $57^{\circ} \mathrm{C} . \mathrm{km}^{-1}\left(\sim 190^{\circ} \mathrm{C} . \mathrm{GPa}^{-1}\right)$ are calculated from RSCM and Grt-Bt thermometry, respectively. Along the Rosis profile and at the base of the micaschists, the calculated gradient reaches $277^{\circ} \mathrm{C} \cdot \mathrm{km}^{-1}\left(\sim 923^{\circ} \mathrm{C} \cdot \mathrm{GPa}{ }^{-1}\right)$. Even if its area is close to the Espinouse migmatitic gneiss, this temperature gradient is too high to invoke heat conduction from the migmatitic core dome through the metasedimentary cover as the possible cause. Field structural analyses reveals that a top-to-the E-NE normal ductile high strain zone is localized along the gneiss core-mantling schist boundary (Aerden, 1998, Aerden \& Malavieille, 1999) that we attribute to the D3 transition zone in agreement with Rabin et al. (2015, Fig. 5). This ductile deformation was responsible for localized thinning in the middle crust during the retrogression history and may be responsible for very high temperature gradient at the base of the metasedimentary envelope.

\section{Low-temperature gradients within the metasedimentary envelope}

The southeastern part of the metasedimentary envelope is not affected by late brittle or ductile extensional shearing. There, temperature gradients of $29^{\circ} \mathrm{C} . \mathrm{km}^{-1}$ and $47^{\circ} \mathrm{C} . \mathrm{km}^{-1}$ ( $97^{\circ} \mathrm{C} . \mathrm{GPa}^{-1}$ and $\left.156^{\circ} \mathrm{C} . \mathrm{GPa}^{-1}\right)$ have been calculated, from RSCM and Grt-Bt thermometry, respectively. Both methods give temperature uncertainty about $\sim \pm 40^{\circ} \mathrm{C}$, but this does not significantly affect the results, since we focus on relative temperatures and gradients. Grt-Bt thermometry gives temperatures of $\sim 50^{\circ} \mathrm{C}$ lower than those

obtained from RSCM. The degree of graphitization corresponds to the degree of prograde metamorphism (Wada et al., 1994) and, owing to the irreversibility of 
graphitization, the analyses graphitic carbon record peak metamorphic temperatures (Beyssac et al., 2002). The significance of temperature obtained from Grt-Bt thermometry is more uncertain and may correspond to peak metamorphism or retrograde mineral reequilibration. In addition, the Grt-Bt gradient is obtained with less than twice the data for the RSCM gradient (Fig. 6c). We suggest that the temperature gradient of $29^{\circ} \mathrm{C}_{\mathrm{km}} \mathrm{k}^{-1}\left(\sim 96^{\circ} \mathrm{C} / \mathrm{GPa}^{-1}\right)$ obtained along the southernmost cross-section from Raman spectroscopy may represent the lowest temperature gradient that prevailed before late ENE extensional shearing.

The question of the cause for this low temperature gradient then arises. It could be also envisaged that the micaschist envelope did not have sufficient time to thermally reequilibrate owing to rapid exhumation. One possible explanation for inefficient thermal conduction could be the numerous graphite rich layers within the micaschist envelope. Indeed, graphite presents an important thermal conductivity anisotropy that can be significantly efficient perpendicular to the basal plane of graphite grains (Enweani et al, 1995). Therefore the structural position of the graphite-rich metasedimentary cover can play the role of a thermal buffer and minimize the thermal impact of dome emplacement on its cover (assuming no significant relative structural displacement between micaschist and deeper migmatites). On the other hand, the ductile high-strain zone along the dome-micaschist envelope boundary may have juxtaposed partially molten crust with cold micaschist that were previously far from the anatectic front (Rey et al., 2011). If this system cooled before it had time to equilibrate, such as may have occurred during late orogenic evolution, thermal balancing would be prevented.

This article is protected by copyright. All rights reserved. 


\section{Comparison with other LP-HT terranes}

The variation of thermal regimes through times reflects changes in orogenic processes (Brown, 2007, 2014). The quantification of thermal gradients, whether synchronous to thickening or thinning, is key information for the understanding of the evolution of the rheology of mature orogenic crust. In this study, gradients that are not perturbed by late deformation are around 20 to $50^{\circ} \mathrm{C} \cdot \mathrm{km}^{-1}\left(\sim 66\right.$ to $\left.166^{\circ} \mathrm{C} . \mathrm{GPa}{ }^{-1}\right)$, slightly hotter than expected. According to the classification of Brown (2007), the European Variscides is dominated by E-HPG metamorphism (Eclogite-high-pressure Granulite). Gradients predicted are between 10 and $20^{\circ} \mathrm{C} . \mathrm{km}^{-1}$ (see fig. 7 in Brown, 2007). However, a similar $P-T$ path and thermal evolution are recorded by late orogenic gneiss domes at the same regional scale. Recent works on the Shuswap complex in the Canadian Cordilleras (Norlander et al., 2002; Zanoni et al., 2014) indicates that exhumation of the gneiss core occurred under conditions of near-isothermal decompression and geothermal gradients of $\sim 40-50^{\circ} \mathrm{C}^{\mathrm{km}}{ }^{-1}\left(\sim 133-166{ }^{\circ} \mathrm{C} . \mathrm{GPa}^{-1}\right)$ that are similar to those calculated in this study. Similarly, gradients between 20 and $30^{\circ} \mathrm{C} . \mathrm{km}^{-1}\left(\sim 66-100^{\circ} \mathrm{C} . \mathrm{GPa}^{-1}\right)$ in the Naxos dome in Greece (Duchêne et al., 2006) were interpreted as heating of the deeper parts of the dome, probably associated with localized thinning during dome formation. In the Variscides, Rey et al. (1997) explained the pervasive high thermal gradients associated with large amount of granites as a consequence of gravitational collapse due to thermal softening of the mature orogenic crust. Similarly, in the Orlica-Snieznik dome of the central Sudetes, Skrzypek et al. (2014) proposed thermal gradients synchronous to crustal thickening of $\sim 30^{\circ} \mathrm{C} . \mathrm{km}^{-1}\left(\sim 100^{\circ} \mathrm{C} . \mathrm{GPa}^{-1}\right)$ deduced from prograde garnet growth modelling. The authors interpreted these gradients by protracted intrusion of granites 
over $10 \mathrm{Ma}$. The late Variscan LP/HT metamorphic event in Iberia is attributed to crustal thickening followed by prolonged thermal relaxation with no additional heat from the mantle is required (Martinez Catalàn et al., 2014). To sum up, elevated geothermal gradients at regional scale gneiss domes can be attributed to a combination of dome core emplacement, with or without additional heat input, and ductile shearing resulting in the collapse of isotherms.

The late-Variscan Agly gneiss dome located in the Pyrenees records a mean thermal gradient at $\sim 40-50^{\circ} \mathrm{C} . \mathrm{km}^{-1}\left(\sim 133-166{ }^{\circ} \mathrm{C} . \mathrm{GPa}^{-1}\right)$ was proposed, with some heat partly provided by injections of mafic magmas in the middle crust (Olivier et al., 2004; Vielzeuf, 1996). This thermal gradient is interpreted as due to thinning in the middle crust, with syn-metamorphic shear zones (Bouhallier et al., 1991). At the base of the

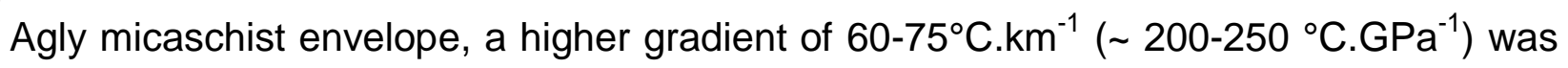
estimated, whereas this value increases to $\sim 125^{\circ} \mathrm{C} . \mathrm{km}^{-1}\left(\sim 417^{\circ} \mathrm{C} . \mathrm{GPa}^{-1}\right)$ close to the migmatitic rocks (Barnolas \& Chiron, 1996). This was interpreted as contact metamorphism between the migmatitic dome and the micaschist envelope (Olivier et al., 2004).

At least during the late stages of their evolution, the MNAZ shares a similar tectonometamorphic evolution as the Velay dome which is the largest late orogenic migmatitic dome in the European Variscan belt located further north-east within the French Massif Central. The history of the Velay dome is reviewed in a recent article by Barbey et al. (2015). The first melting events (named M1 and M2) are linked to crustal thickening. 
The last Late Carboniferous melting events M3 and M4 (from Barbey et al., 2015) operated under the same $P-T$ conditions as reported in this study i.e. peak conditions at $\sim 700{ }^{\circ} \mathrm{C}$ and $0.6-0.7 \mathrm{GPa}$ followed by decompression and melting up to $0.4 \mathrm{GPa}$. This M4 event is slightly hotter in the Velay dome $\left(\sim 800^{\circ} \mathrm{C}\right)$, whereas re-heating has not been observed at this stage in the MNAZ. Recently published geochronological data (Roger et al., 2015) indicated a similar range of ages for the main melting event in the MNAZ (310 - $300 \mathrm{Ma})$.

\section{CONCLUSIONS}

Based on field studies, classical petrology, thermometry and thermodynamic modelling, we propose a tectono-thermal evolution for the MNAZ gneiss core as well as its metasedimentary cover. The migmatitic gneisses record a clockwise evolution culminating at $\sim 725{ }^{\circ} \mathrm{C}$ and $0.8 \mathrm{GPa}$, leading to partial melting. Within the metasedimentary cover, we have recognized both high temperature and low temperature gradients. These features are common to other gneiss domes and can be explained by a synchronous effect of dome core emplacement and ductile shearing.

Finally, further work with in situ geochronology is needed in order to unravel rates and scales of anatectic processes in the middle crust as well as the associated thermal evolution of the upper crust during gneiss dome formation.

\section{ACKNOWLEDGMENTS}

This project was funded by a INSU/SYSTER program granted to B. Cenki-Tok. Additional support was provided by US NSF grant EAR-1050020 to Ch. Teyssier and 
D.L. Whitney. K. Freville thanks O. Beyssac for assistance during RSCM analysis. We thank the support of the Microsonde Sud equipment. AL and JLR thank the bachelor and master students of the University of Montpellier 2 who participated to the mapping of isograds in the eastern termination of the dome. The manuscript benefited from constructive reviews from R. Palin and an anonymous reviewer. M. Brown is thanked for editorial handling.

\section{REFERENCES}

Aerden, D. G., 1998. Tectonic evolution of the Montagne Noire and a possible orogenic model for syncollisional exhumation of deep rocks, Variscan belt, France. Tectonics, $17,62-79$.

Aerden, D.G.A.M \& Malavieille, J., 1999. Origin of a large-scale fold nappe in the montagne noire, variscan belt, france. Journal of Structural Geology, 2, 1321-1333.

Alabouvette, B., Demange, M., Guérangé-Lozes, J. \& Ambert, P., 2003. Notice et carte géologique au 1/250000: Montpellier.

Althoff, F., Barbey, P. \& Pons, J., 1994. La charnockite d'Ansignan et le granite de Saint-Arnac, témoins d'une extension crustale d'âge hercynien dans le massif de l'Agly (Pyrénées orientale, France). Comptes Rendus de l'Académie des Sciences de Paris, 319, série II, 239- 246.

Baldwin, J.A., Powell, R., Brown, M., Moraes, R. \& Fuck, R.-A., 2005. Modelling of mineral equilibria in ultrahigh-temperature metamorphic rocks from the AnapolisItaucu Complex, central Brazil. Journal of Metamorphic Geology, 23, 511-531

Barbey, P., Villaros, A., Marignac, C. \& Montel, J.-M., 2015. Multiphase melting, magma 
emplacement and P-T-time path in late-collisional context: the Velay example (Massif central, France). Bulletin de la Société Géologique de France, 186, 2-3, 93116.

Bard, J-P. \& Rambeloson, R., 1973. Metamorphisme plurifacial et sens de variation du degree geothermique Durant la tectogenese polyphase hercynienne dans la partie orientale de la zone axiale de la Montagne Noire (massif du Caroux, sud du Massif Central français). Bulletin de la Société Géologique de France, 15, 579-586.

Barnolas, A. \& Chiron, J.C., 1996. Synthèse géologique et géophysique des Pyrénées: Introduction, Géophysique, Cycle hercynien. Bureau des Recherches Minières et Géologiques Eds.

Beaud, F., 1985. Etude structurale de la zone axiale orientale de la Montagne noire (sud du Massif central français): détermination des mécanismes de déformation; relation avec les nappes du versant sud. PhD. Université de Montpellier.

Beyssac, O., Goffé, B., Chopin, C. \& Rouzaud, J.-N., 2002. Raman spectra of carbonaceousmaterial in metasediments: a new geothermometer. Journal of metamorphic Geology, 20, 859-871.

Bogdanoff, S., Collomb, P. \& Ellenberger, F., 1967. Métamorphisme et effet de couverture dans la zone axiale de la Montagne Noire (Espinouse et Caroux, Herault). Comptes Rendus de la Société Geologique de France, 6, 223-224.

Bogdanoff, S., 1969. Sur la sillimanite de la zone axiale de la Montagne Noire (Monts de l'Espinous, Hérault). Comptes Rendus de l'Académie des Sciences de Paris, 268, 2163-2166.

Bodganoff, S., Donnot, M. \& Ellenberger, F., 1984. Notice explicative de la feuille 
Bédarieux 1/50.000. Bureau des Recherches Minières et Géologiques Eds, 1984, 2007.

Bouchardon, J.L., Dechomets, R. \& Demange, M., 1979. A propos du disthène en roche dans les micaschistes et gneiss du synclinal de Rosis et du flanc Sud, zone axiale de la Montagne Noire. Comptes Rendus de l'Académie des Sciences de Paris, 288, 1067-1069.

Bouhallier, H., Choukroune, P. \& Ballevre, M., 1991. Evolution structurale de la croûte profonde Hercynienne : exemple du massif de l'Agly (Pyrénées Orientales, France). Comptes Rendus de l'Académie des Sciences de Paris, 312, 647-654.

Brown, M., 2007. Metamorphic conditions in orogenic belts: A record of secular change. International Geology Review, 49, 193-234.

Brown, M., 2014. The contribution of metamorphic petrology to understanding lithosphere evolution and geodynamics. Geoscience Frontiers, 5, 553-569.

Brun, J. P. \& van den Driessche, J., 1994. Extensional gneiss domes and detachment fault systems; structure and kinematics. Bulletin de la Société Géologique de France, 165, 519-530.

Brunel, M. \& Lansigu, C., 1997. Déformation et cinématique de mise en place du dôme de la zone axiale de la Montagne Noire: signification des nodules à quartzsillimanite (Massif central français). Comptes Rendus de l'Académie des Sciences de Paris, 325, 517-523.

Charles, N., Faure, M. \& Chen, Y., 2009. The Montagne Noire migmatitic dome emplacement (French Massif Central): new insights from petrofabric and AMS studies. Journal of Structural Geology, 31, 1423-1440. 
de Capitani, C. \& Petrakakis K., 2010. The computation of equilibrium assemblage diagrams with Theriak/Domino software. American Mineralogist, 95,1006-1016.

Demange, M., 1985. The eclogite-facies rocks of the Montagne Noire, France. Chemical Geology, 50, 173-188.

Demange, M., 1999. Evolution tectonique de la Montagne Noire: un modèle en transpression. Comptes Rendus de l'Académie des Sciences de Paris, 329, 823829.

Demange, M. \& Gattoni, X., 1978. Le métamorphisme progressif des formations d'origine pélitique du flanc sud du massif de l'Agout. Isograde et faciès de métamorphisme. Bulletin de Minéralogie, 101, 334-349.

Denèle, Y., Olivier, P., Gleizes, G. \& Barbey, P., 2009. Decoupling between the middle and upper crust during transpression-related lateral flow: Variscan evolution of the Aston gneiss dome (Pyrenees, France). In "Hot Orogen" eds: Chardon, D. \& Teyssier, C. Tectonophysics, Special Publication, 477, 244-261.

Denèle, Y., Olivier, P., Gleizes, G. \& Barbey, P., 2007. The Hospitalet gneiss dome (Variscan Pyrenees) revisited: lateral flow during transpression in the middle crust. Terra Nova, 19, 445-453.

Duchêne, S., Aïssa, R. \& Vanderhaeghe, O, 2006. Pressure-Temperature-time Evolution of Metamorphic Rocks from Naxos (Cyclades, Greece): Constraints from Thermobarometry and Rb/Sr dating. Geodinamica Acta, 19, 299-319.

Echtler, H. \& Malavieille, J., 1990. Extensional tectonics, basement uplift and StephanoPermian collapse basin in a late Variscan metamorphic core complex (Montagne Noire, Southern Massif Central). Tectonophysics, 177, 125-138.

This article is protected by copyright. All rights reserved. 
England, P.C. \& Thompson, A.B., 1984. Pressure-Temperature-Time paths of regional metamorphism. Part I: Heat transfer during the evolution of regions of thickened continental crust. Journal of Petrology, 25, 894-928.

Enweani, B.N., Davis, J.W. \& Haasz, A.A., 1995. Thermal diffusivity/conductivity of doped graphite. Journal of Nuclear Materials, 224, 245-253.

Faure, M., 1995. Late orogenic carboniferous extensions in the variscan french massif central. Tectonics, 14, 132-153, 1995.

Faure, M., Cocherie, A., Gaché, J., Esnault, C., Guerrot, C., Rossi, P., Wei, L. \& Qiuli, L., 2014. Middle Carboniferous intracontinental subduction in the Outer Zone of the Variscan Belt (Montagne Noire Axial Zone, French Massif Central): multimethod geochronological approach of polyphase metamorphism. Geological Society of London Special Publication, 405, SP405.2, doi:10.1144/SP405.2.

Ferry, J.M. \& Spear, F.S., 1978. Experimental calibration of the partitioning of Fe and Mg between biotite and garnet. Contributions to Mineralogy and Petrology, 66, 113117.

Franke, W., Doublier, M. P., Klama, K., Potel, S. \& Wemmer, K., 2011. Hot metamorphic core complex in a cold foreland. International Journal of Earth Sciences, 100, 753-786.

Geze, B., 1949. Etude géologique de la Montagne Noire et des Cévennes méridionales. Bulletin de la Société Géologique de France, 1, 281-285.

Holland, T. J. B. \& Powell, R., 1998. An internally consistent thermodynamic dataset for phases of petrological interest.. Journal of Metamorphic Geology, 16, 309-343.

Kelsey, D.E., White, R.W. \& Powell, R., 2005. Calculated phase equilibria in $\mathrm{K}_{2} \mathrm{O}-\mathrm{FeO}-$ 
$\mathrm{MgO}-\mathrm{Al}_{2} \mathrm{O}_{3}-\mathrm{SiO}_{2}-\mathrm{H}_{2} \mathrm{O}$ for silica-undersaturated sapphirine-bearing mineral assemblages. Journal of Metamorphic Geology, 23, 217-239.

Lardeaux, J.-M., 2014. Deciphering orogeny: a metamorphic perspective. Examples from European Alpine and Variscan belts. Part II: Variscan metamorphism in the French Massif Central - A review. Bulletin de la Société Géologique de France, $185,281-310$.

Laumonier, B., Marignac, C. \& Kister, P., 2010. Polymétamorphism et evolution crustale dans les Pyrénées orientales pendant l'orogenèse varisque au Carbonifère supérieur. Bulletin de la Societé Géologique de France 181, 411-428.

Ledru, P., Courrioux G., Dallain, C., Lardeaux J.-M., Montel J.-M., Vanderhaeghe O. \& Vitel, G., 2001. The Velay dome (French Massif Central): melt generation and granite emplacement during orogenic evolution. Tectonophysics, 342, 207-237.

Malavieille, J., 2010. Impact of erosion, sedimentation, and structural heritage on the structure and kinematics of orogenic wedges: Analog models and case studies. GSA Today, 20.

Martinez Catalàn, J.R., Rubio Pascual, F.J., Diez Montes, A. et al., 2014. The late Variscan HT/LP metamorphic event in NW and Central Iberia: relationships to crustal thickening, extension, orocline development and crustal evolution. Geological Society, London, Special Publications, 405, 225-247

Matte, P., Lancelot, J. \& Mattauer, M., 1998. La zone axiale hercynienne de la Montagne Noire n'est pas un «metamorphic core complex » extensif mais un anticlinal post-nappe à cœur anatectique. Geodinamica Acta, 11, 13-22.

Mezger, J. E., 2009. Transpressional tectonic setting during the main Variscan 
deformation: evidence from four structural levels in the Bossòst and AstonHospitalet mantled gneiss domes, central Axial Zone, Pyrenees. Bulletin de la Société Géologique de France, 180, 199-207.

Mezger, J. E., 2005. Comparison of the western Aston-Hospitalet and the Bossòst domes: Evidence for polymetamorphism and its implications for the Variscan tectonic evolution of the Axial Zone of the Pyrenees. In: (eds) Carosi, R., Dias, R., lacopini, D. \& Rosenbaum, G., The southern Variscan belt, Journal of the Virtual Explorer, Electronic.

Nicollet, C., 1978. Etude pétrologique, géochimique et structurale des terrains cristallins antépermiens du versant sud du Lévezou (Massif central français), origine des groupes leptyno-amphiboliques. Unpublished PhD, Université de Montpellier, 125 pp.

Norlander, B.H., Whitney, D.L., Teyssier, C. \& Vanderhaeghe, O., 2002. High temperature decompression of the Shuswap metamorphic core complex, Canadian Cordillera. Lithos, 61, 103-125.

Olivier, P., Gleizes, G. \& Paquette, J.L., 2004. Gneiss domes and granite emplacement in an obliquely convergent regime: New interpretation of the Varsican Agly Massif (Eastern Pyrenees, France). Geological Society of America, Special Paper, 380, 229-242.

Ourzik, A., Debat, P. \& Mercier, A., 1991. Metamorphic Evolution of the N and Ne Parts of the Montagne Noire Axial Zone (southern Massif-Central, France), Comptes Rendus de l'Académie des Sciences de Paris, 313, 1547-1553.

Pitra, P., Poujol, M., Van Den Driessche, J., Polivet, J.C. \& Paquette, J.L., 2012. Early 
Permian extensional shearing of an ordovician granite: The saint- eutrope "c/s- like" orthogneiss (montagne noire, French massif central). Comptes Rendus Géoscience, 344, 377-384.

Rabin, M., Trap, P., Carry, N., Freville, K., Cenki-Tok, B., Lobjoie, C., Goncalves, P. \& Marquer, D., 2015. Strain partitioning along the anatectic front in the Variscan Montagne Noire massif (Southern French Massif Central). Tectonics, in press.

Rambeloson, R., 1972. Tectonique, microtectonique, et métamorphisme dans le massif gneissique du "Caroux" et son enveloppe mica schisteuse (extrémité sud-est de la zone axiale de la Montagne Noire). Unpublished PhD, Université de Montpellier.

Rey, P., Burg, J.-P. \& Casey, M, 1997. The Scandinavian Caledonides and their relationship to the Variscan belt. Burg, J.-P. \& Ford, M. (eds), 1997, Orogeny Through Time, Geological Society Special Publication, 121, 179-200.

Rey, P., Teyssier, C., Kruckenberg, S.C. \& Whitney, D.L., 2011. Viscous collision in channel explains double domes in metamorphic core complexes. Geology, 39, 387390.

Rey, P., Teyssier, C., Kruckenberg, S.C. \& Whitney, D.L., 2012. Viscous collision in channel explains double domes in metamorphic core complexes. Geology, Forum Reply, October, 2012.

Roger, F., Teyssier, Ch., Respaut, J.P., Rey, P., Jolivet, M., Whitney, D.L., Paquette, J.P. \& Brunel, M., 2015. Timing of deformation and exhumation of the Montagne Noire double dome, French Massif Central. Tectonophysics, 640-641, 53-69.

Roques, M., 1941. Les schistes cristallins de la partie sud ouest du Massif Central francais. Explication carte géologique de France. Bureau des Recherches Minières 
et Géologiques Eds.

Schuilling, R., 1960. Le dôme gneissique de l'Agout (Tarn et Herault). Mémoire Société géologique de France, 91, 58 p.

Skrzypek, E., Lehmann, J., Szczepanski, J., Anczkiewicz, R., Stipska, P., Schulmann, K., Krröner, A. \& Bialek, D., 2014. Time-scale of deformation and intertectonic phases revealed by $\mathrm{P}-\mathrm{T}-\mathrm{D}-\mathrm{t}$ relationships in the orogenic middle crust of the Orlica-Snieznik Dome, Polish/Czech Central Sudetes. Journal of Metamorphic Geology, 32, 981-1003.

Soula, J. C., Debat, P., Brusset, S., Bessière, G., Christophoul, F. \& Déramond, J., 2001. Thrust-related, diapiric, and extensional doming in a frontal orogenic wedge: example of the Montagne Noire, Southern French Hercynian Belt. Journal of Structural Geology, 23, 1677-1699.

Teyssier, C. \& Whitney, D.L., 2002. Gneiss domes and orogeny. Geology, 30, 11391142.

Thompson, A. B. \& England, P.C., 1984. Pressure-temperature-time paths of regional metamorphism: Part II: Some petrological constraints from mineral assemblages in metamorphic rocks. Journal of Petrology, 25, 929-955.

Thompson, P. H. \& Bard, J. P., 1982. Isograds and mineral assemblages in the eastern axial zone, Montagne Noire (France): implications for temperature gradients and PT history. Canadian Journal of Earth Sciences, 19, 129-143.

Tirel, C., Brun, J.-P. \& Burov, E., 2004. Thermomechanical modeling of extensional gneiss domes, in Whitney, D.L., Teyssier, C. \& Siddoway, C.S., eds, Gneiss Domes in Orogeny. Geological Society of America Special Paper, 380, 67-78.

This article is protected by copyright. All rights reserved. 
Van Den Driessche, J. \& Brun, J.P. 1989. Un modèle cinématique de l'extension paleozoïque supérieur dans le Sud du Massif Central. Comptes Rendus de l'Académie des Sciences de Paris, 309, 1607-1613.

Van den Driessche, J. \& Brun, J.P., 1992. Tectonic evolution of the Montagne Noire (French Massif Central): a model of extensional gneiss dome. Geodinamica Acta, 5, 85-99.

Van Den Driessche, J. \& Pitra, P. 2012. Viscous collision in channel explains double domes in metamorphic core complexes. Geology, Forum Comment, October 2012.

Vielzeuf, D., 1996. Les massifs nord-pyrénéens à soubassement granulitique, in Barnolas, A., and Chiron, J.C. eds Synthèse géologique et géophysique des Pyrénées: Introduction, Géophysique, Cycle hercynien. Bureau des Recherches Minières et Géologiques Eds, 1, 502-521.

Wada, H., Tomita, T., Luchi, K., Ito, M. \& Morikiyo, T., 1994. Graphitization of carbonaceous matter during metamorphism with reference to carbonate and pelitic rocks of contact and regional metamorphism, Japan. Contributions to Mineralogy and Petrology, 118, 217-228

White, R.W., Powell, R. \& Clarke, G.L., 2002. The Interpretation of reaction textures in Fe-rich metapelitic granulites of the Musgrave Block, central Australia: Constraints from mineral equilibria calculations in the system $\mathrm{K}_{2} \mathrm{O}-\mathrm{FeO}-\mathrm{MgO}-\mathrm{Al}_{2} \mathrm{O}_{3}-\mathrm{SiO}_{2}-\mathrm{H}_{2} \mathrm{O}$ $\mathrm{TiO}_{2}-\mathrm{Fe}_{2} \mathrm{O}_{3}$. Journal of Metamorphic Geology, 20, 41-55

White, R.W., Powell, R. \& Holland, T.J.B., 2007. Progress relating to calculation of partial melting equilibria for metapelites. Journal of Metamorphic Geology, 25, 511527.

Whitney, D.L. \& Evans, B.W., 2010. Abbreviations for names of rock-forming minerals. American Mineralogist, 95, 185-187.

Whitney, D.L., Roger F., Teyssier, C. \& Respaut, J.-P., 2015. Syn-collapse eclogite metamorphism and exhumation of deep crust in a migmatite dome: The P-T-t record of the youngest Variscan eclogite (Montagne Noire, French Massif Central).

This article is protected by copyright. All rights reserved. 
Earth and Planetary Science Letters, 430, 224-234

Whitney, D.L., Teyssier, C. \& Vanderhaeghe, O., 2004. Gneiss domes and crustal flow. Geological Society of America Special Papers, 380, 15-33.

Whitney, D.L., Teyssier, C., Rey, P. \& Buck, W.R., 2013. Continental and oceanic core complexes. Geological Society of America Bulletin, doi:10.1130/B30754.1.

Williams, Q., 1995. Infrared Raman and Optical Spectroscopy of Earth Materials. AGU, 291-301.

Zanoni, D., Kuiper, Y. D. \& Williams, P.F., 2014. Pre- to post-Cordilleran transposition history of Joss Mountain: Insights into the exhumation of the Shuswap complex, southeastern Canadian Cordillera. Lithosphere, 6, 419-442.

Received 2 April 2015; revision accepted 3 March 2016.

\section{FIGURE CAPTION}

Figure 1. (a): Location of Montagne Noire gneiss dome in European Variscan basement. (b): Simplified geological and structural map of the Montagne Noire dome. (c): Eastern termination of the Montagne Noire dome indicating lithologies, boundaries of metamorphic zones as well as location of samples selected for thermobarometry in the metapelitic cover and equilibrium assemblage diagram calculation for samples from the core of the dome.

Figure 2: Microphotographs, plane polarized light. (a). Cordierite-sillimanite nodules in MNC04; (b). Corroded garnet in MNC17.

Figure 3: Equilibrium assemblage diagrams for three migmatitic orthogneiss within the core of the Montagne Noire dome. (a). MNC04; (b). MNC17; (c). MN11-47. See location on Fig. 1. Dashed lines correspond to isopleths of the almandine or grossular component in garnet.

Figure 4: Microphotographs, plane polarized light. (a-g): Mineral assemblage observed in defined metamorphic zone. See text for explanation; (h). Kyanite in schist $\mathrm{X}$ sample MN11-98; (i): Example of garnet-biotite couple used for Grt-Bt thermometry; (j): Synkinematic graphite in MNC19.

Figure 5: Profiles selected for thermobarometry in the metapelitic cover of the dome.

This article is protected by copyright. All rights reserved. 
Figure 6: Garnet-biotite and RSCM thermobarometry gradients. Length represents the distance of sample from an arbitrary origin.

Figure 7: Schematic P-T diagram summarizing the thermal evolution of core and cover in the Montagne Noire.

Table 1: Representative microprobe analysis of garnet, biotite, muscovite in samples used for the equilibrium assemblage diagrams approach.

Table 2: List of solution models used for thermodynamic modelling with DominoTheriak.

Table 3: Bulk analysis of sample used for the equilibrium assemblage diagrams approach. Table 4: Temperature obtained by RSCM and garnet-biotite thermometry.

This article is protected by copyright. All rights reserved. 


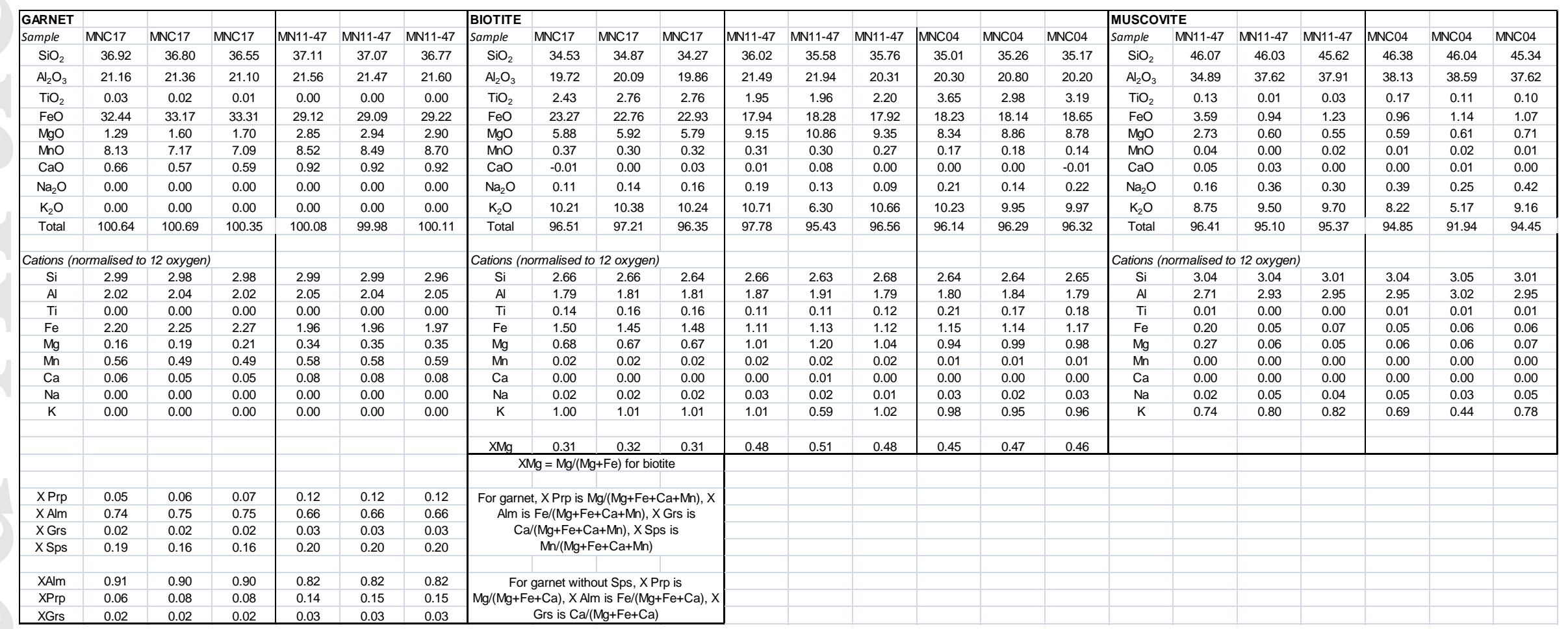

\begin{tabular}{|l|c|l|l|l|}
\hline Mineral & Abbreviation & Reference & End-members \\
\hline & Whitney \& Evans, 2010 & \\
\hline Biotite & Bt & White et al. , 2007 & phlogopite, annite, obiotite, eastonite, tbiotite \\
\hline Phengitic White Mica & Ms & Coggon \& Holland, 2002 & muscovite, celadonite, Fe-celadonite, paragonite \\
\hline Garnet & Grt & White et al. , 2007 & almandine, pyrope, grossular \\
\hline Cordierite & Crd & Holland \& Powell, 1998 & cordierite, Fe-cordierite, Mn-cordierite, hydr-cordierite \\
\hline Feldspar & Fsp & Baldwin et al. , 2005 & sanidine, high-albite, anorthite \\
\hline Orthopyroxene & Opx & White et al., 2002 & enstatite, ferrosilite, Mg-Tscher.pyx, FM.px, mots \\
\hline Melt & Liq & White et al., 2007 & silica8.liq, albite.liq, K-feldspar.liq, anorthite.liq, sillimanite8.liq, forsterite8.liq, fayalite8.liq, H2O.liq \\
\hline
\end{tabular}

This article is protected by copyright. All rights reserved. 


\begin{tabular}{|c|ccc|}
\cline { 2 - 4 } \multicolumn{1}{c|}{} & \multicolumn{3}{|c|}{ Samples } \\
\hline Oxides (Wt\%) & MNC-04 & MNC-17 & MN 11-47 \\
\hline $\mathrm{SiO}_{2}$ & 65.19 & 75.10 & 67.93 \\
$\mathrm{Al}_{2} \mathrm{O}_{3}$ & 15.63 & 13.46 & 14.42 \\
$\mathrm{Fe}_{2} \mathrm{O}_{3}$ tot & 6.01 & 2.25 & 6.22 \\
$\mathrm{MgO}$ & 2.23 & 0.33 & 1.94 \\
$\mathrm{CaO}$ & 0.59 & 0.50 & 1.02 \\
$\mathrm{Na} 2 \mathrm{O}$ & 1.86 & 2.60 & 3.29 \\
$\mathrm{~K} 2 \mathrm{O}$ & 5.13 & 4.93 & 3.82 \\
$\mathrm{TiO} 2$ & 0.72 & 0.15 & 0.38 \\
$\mathrm{MnO}$ & 0.06 & 0.04 & 0.13 \\
$\mathrm{P} 2 \mathrm{O}_{5}$ & 0.21 & 0.21 & 0.20 \\
$\mathrm{Ba}$ & 0.16 & 0.02 & 0.04 \\
$\mathrm{Sr}$ & 0.02 & 0.00 & 0.01 \\
$\mathrm{LOI} @ 110^{\circ} \mathrm{C}$ & 0.27 & 0.16 & 0.04 \\
$\mathrm{LOI@} 1000^{\circ} \mathrm{C}$ & 1.70 & 0.56 & 0.53 \\
$\mathrm{Total}$ & 99.77 & 100.32 & 99.97 \\
\hline
\end{tabular}

\begin{tabular}{|c|c||c|c|c||c|c|c|}
\hline \multicolumn{2}{|c||}{} & \multicolumn{3}{c||}{$R P$} & \multicolumn{3}{c|}{ ECP } \\
\hline Samples & $\begin{array}{c}\text { RSCM } \\
{ }^{\circ} \mathrm{C}\end{array}$ & Samples & $\begin{array}{c}\text { RSCM } \\
{ }^{\circ} \mathrm{C}\end{array}$ & $\begin{array}{c}\text { Grt-Bt } \\
{ }^{\circ} \mathrm{C}\end{array}$ & Samples & $\begin{array}{c}\text { RSCM } \\
{ }^{\circ} \mathrm{C}\end{array}$ & $\begin{array}{c}\text { Grt-Bt } \\
{ }^{\circ} \mathrm{C}\end{array}$ \\
\hline STGR15 & $549 \pm 35$ & D8 & - & $644 \pm 35$ & MN19 & $586 \pm 31$ & $543 \pm 27$ \\
STGR16 & $566 \pm 38$ & D5 & - & $613 \pm 32$ & MN13 & $586 \pm 20$ & $509 \pm 24$ \\
STGR19 & $568 \pm 32$ & D13 & $582 \pm 20$ & - & MN17 & $578 \pm 21$ & $542 \pm 26$ \\
STGR21 & $482 \pm 25$ & CMS5 & - & $555 \pm 27$ & SR1 & $583 \pm 14$ & - \\
STGR25 & $448 \pm 31$ & P5 & $593 \pm 20$ & - & F1 & $573 \pm 31$ & - \\
STGR13 & $462 \pm 21$ & P2 & $587 \pm 20$ & - & MN49 & $576 \pm 24$ & $522 \pm 26$ \\
STGR22 & $545 \pm 43$ & PP1C & $566 \pm 30$ & $522 \pm 26$ & SR12 & $563 \pm 21$ & - \\
STGR8 & $465 \pm 8$ & SPP4A & $575 \pm 25$ & - & SE1 & $583 \pm 30$ & - \\
& & P23 & $575 \pm 31$ & - & MN33 & $603 \pm 18$ & - \\
& & D15 & - & $606 \pm 30$ & SR7 & $569 \pm 22$ & - \\
& & MN9' & - & $565 \pm 27$ & LV8Bb & - & $427 \pm 22$ \\
& & CMS1 & - & $555 \pm 27$ & MN32 & & \\
\hline
\end{tabular}

This article is protected by copyright. All rights reserved. 

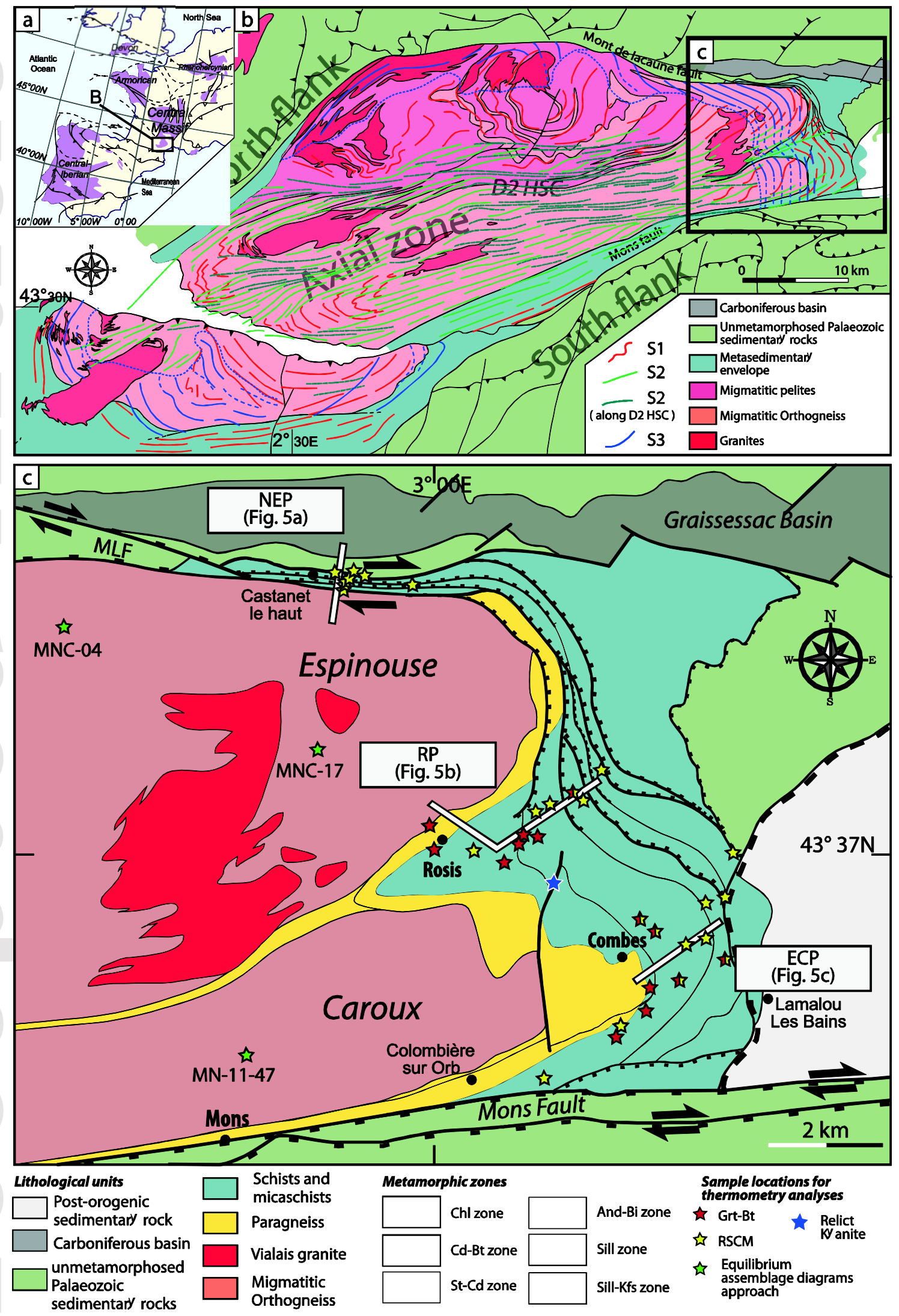

This article is protected by copyright. All rights reserved. 


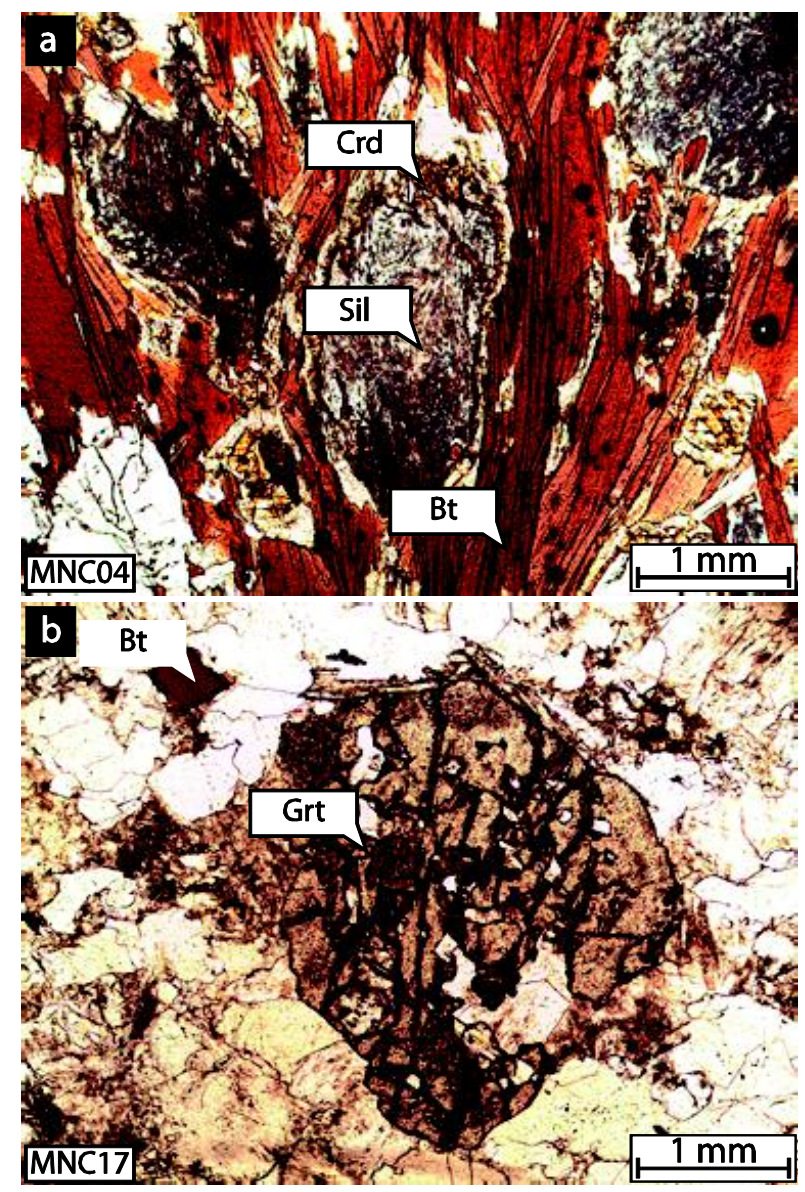

This article is protected by copyright. All rights reserved. 

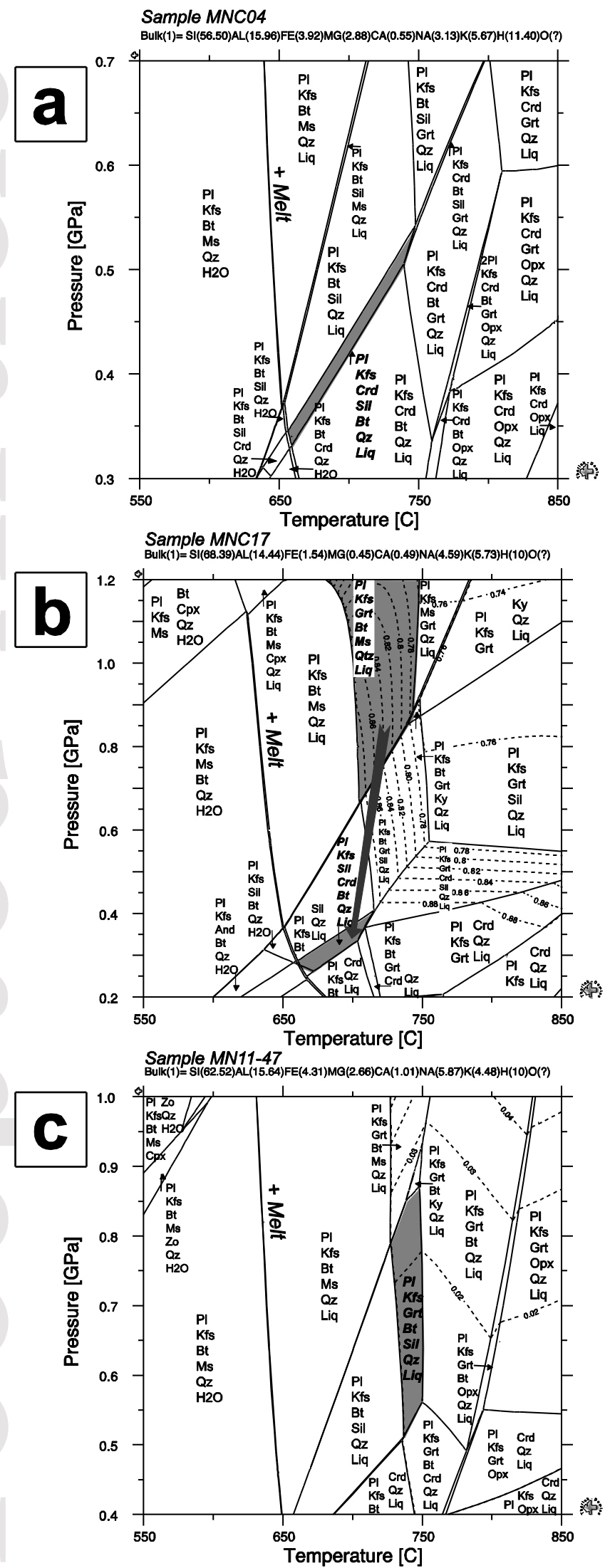

This article is protected by copyright. All rights reserved. 

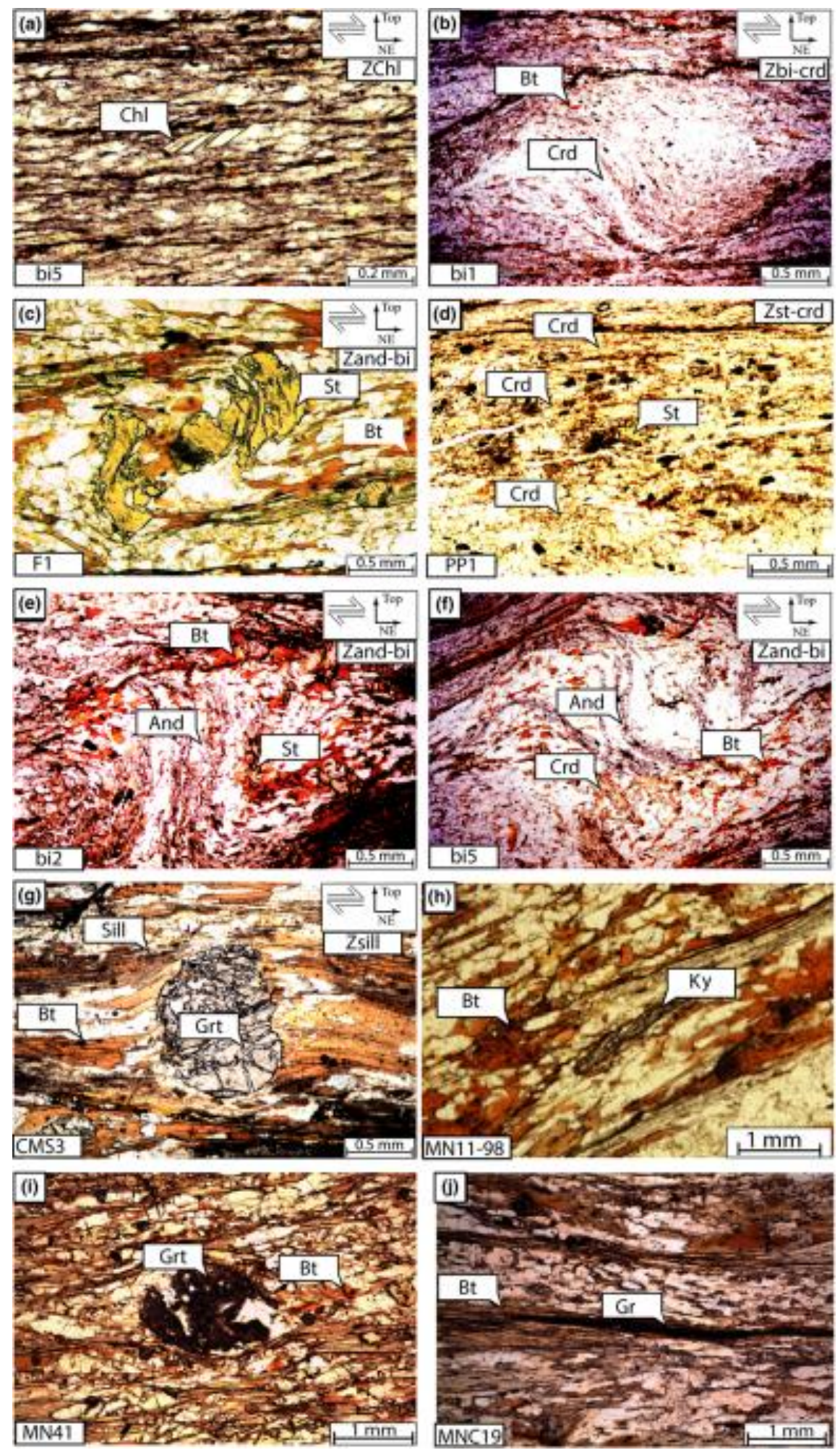


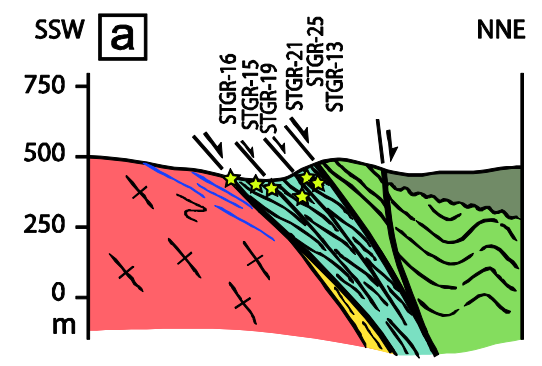

Lithological units

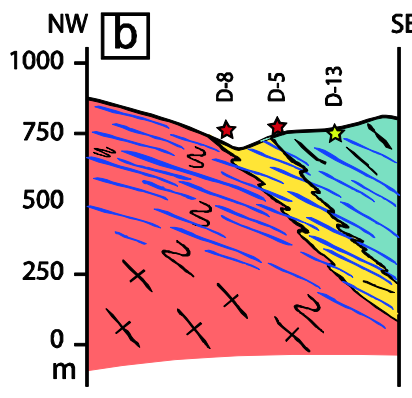

SE SW

$\square$ Carboniferous basin

unmetamorphosed Palaeozoic
sedimentary rocks

Schists and micaschists

(Schists X unit)

$\square$ Paragneiss

Orthogneiss

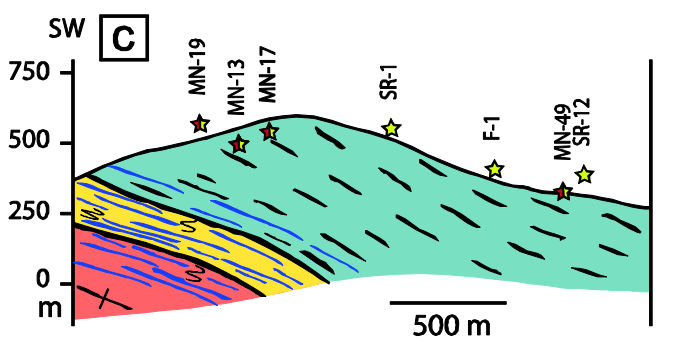

Sample locations for

thermometry analyses

NE

Grt-Bt

s $\mathrm{RSCM}$

Structure

S3 foliation (blue)

$\searrow$ s1 foliation (black)

W Late brittle-ductile faults

This article is protected by copyright. All rights reserved. 

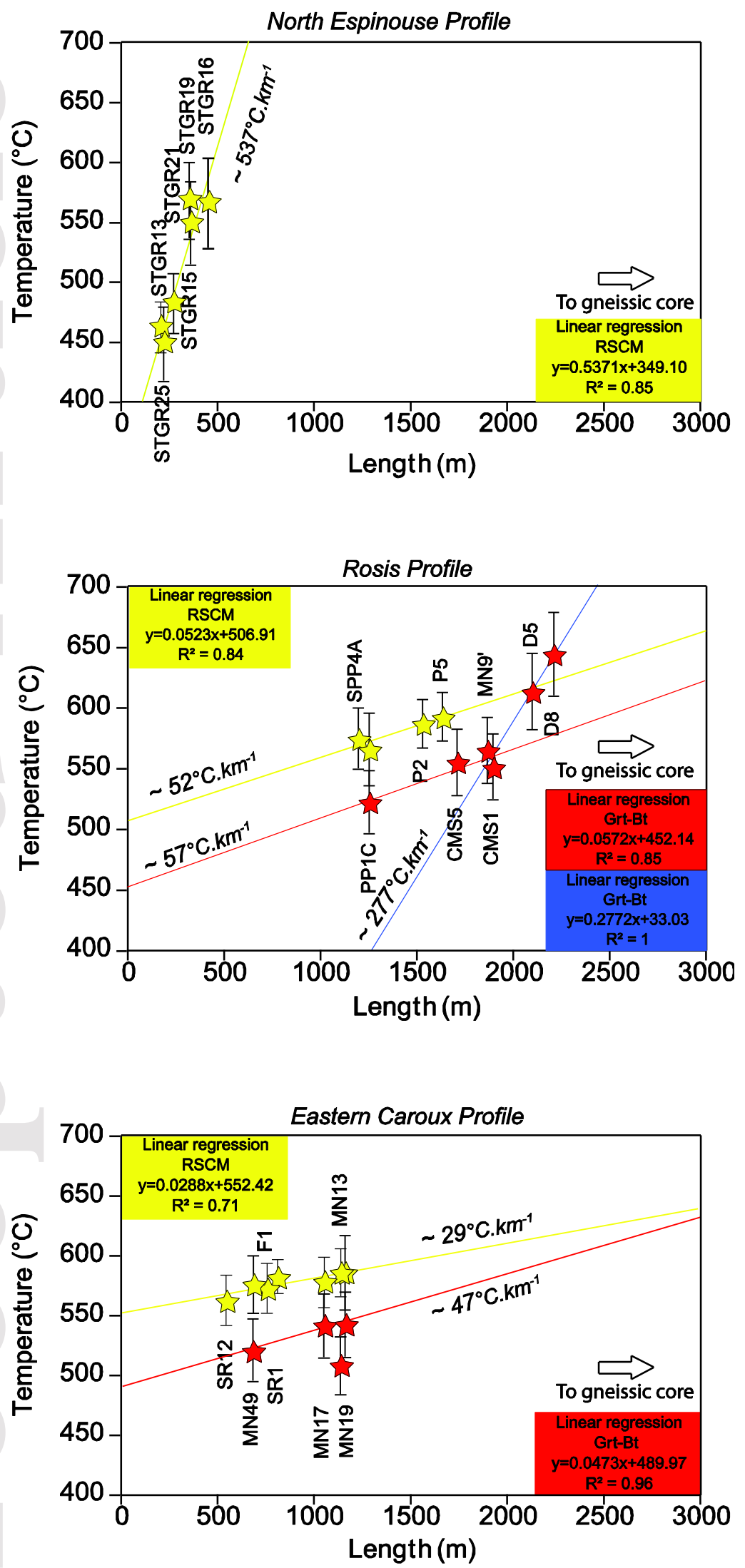

This article is protected by copyright. All rights reserved. 


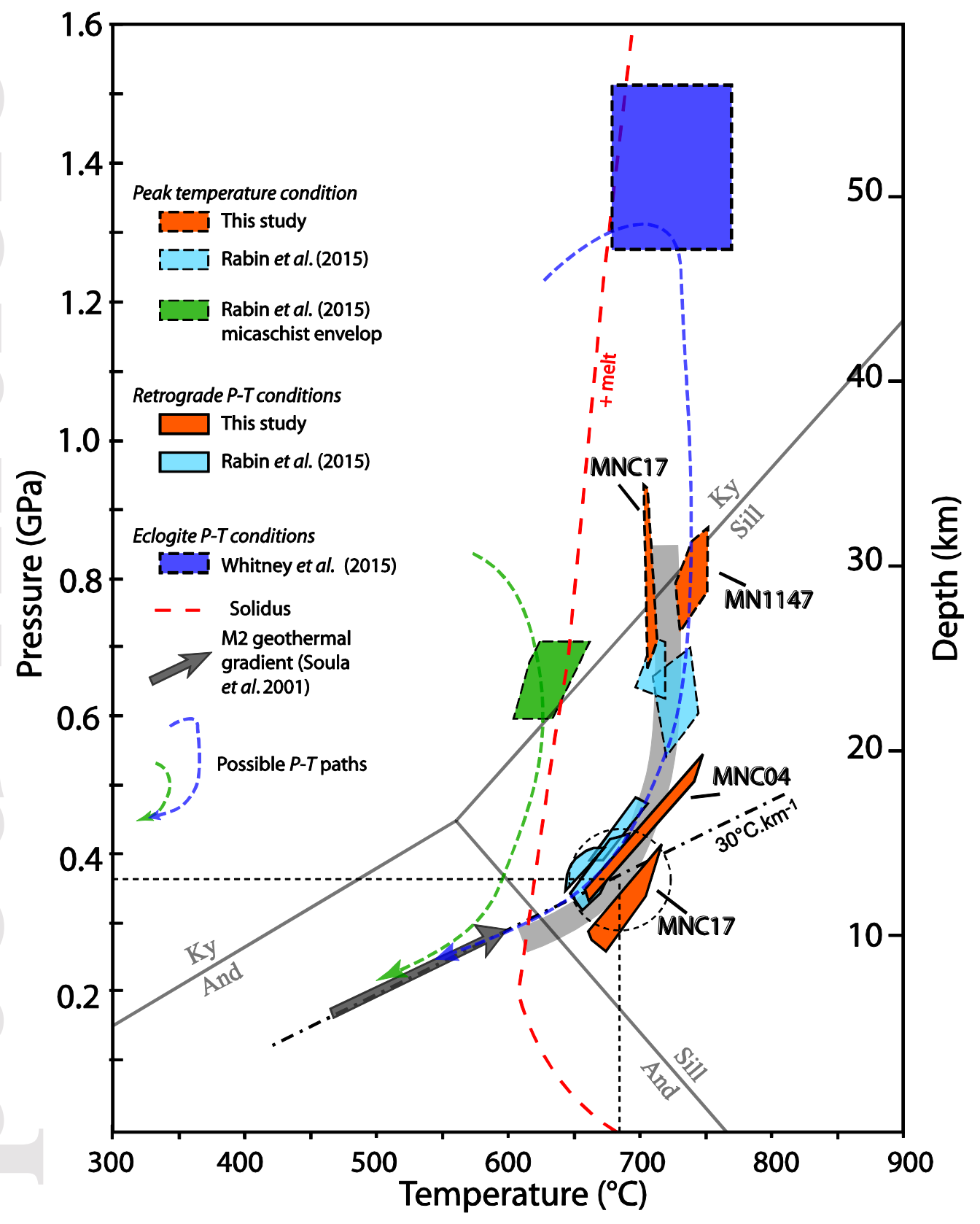

This article is protected by copyright. All rights reserved. 